\title{
PREVALENCE AND FACTORS ASSOCIATED WITH MUSCULOSKELETAL PAIN IN HOSPITAL CLEANING WORKERS
}

\author{
Emanuelli Mancio Ferreira da Luz', Tânia Solange Bosi de Souza Magnago², Patrícia Bitencourt Toscani Greco3, \\ Juliana Dal Ongaro", Tais Carpes Lanes ${ }^{5}$, Jadir Camargo Lemos ${ }^{6}$
}

${ }^{1}$ M.Sc. in Nursing. Nurse, Irmandade da Santa Casa de Caridade de São Gabriel. São Gabriel, Rio Grande do Sul, Brazil. E-mail: emanuelli_ferreira@hotmail.com

${ }^{2}$ Ph.D. in Nursing. Professor, Nursing Department and Graduate Program in Nursing (PPGEnf), Universidade Federal de Santa Maria (UFSM). Santa Maria, Rio Grande do Sul, Brazil. E-mail: tmagnago@terra.com.br

${ }^{3}$ Doctoral student in Nursing in PPGEnf/UFSM. Professor, Undergraduate Nursing Program, Universidade Regional Integrada do Alto Uruguai e das Missões (URI) - Campus Santiago. Santiago, Rio Grande do Sul, Brazil. E-mail: pbtoscani@hotmail.com

${ }^{4}$ Undergraduate Nursing Student UFSM. Scientific Initiation Grantee Fipe Jr./UFSM. Santa Maria, Rio Grande do Sul, Brazil. E-mail: dongaro.ju@gmail.com

${ }^{5}$ Undergraduate Nursing Student UFSM. Scientific Initiation Grantee PROIC-HUSM. Santa Maria, Rio Grande do Sul, Brazil. E-mail: taislanes_rock@hotmail.com

${ }^{6}$ Ph.D. in Production Engineering. Professor, Physiotherapy Department, UFSM. Santa Maria, Rio Grande do Sul, Brazil. E-mail: jadir.lemos@gmail.com

\section{ABSTRACT}

Objective: to assess the prevalence and the factors associated with the occurrence of musculoskeletal pain in hospital cleaning workers. Method: cross-sectional study, involving 157 outsourced workers at a university hospital in the state of Rio Grande do Sul, Brazil. The data were collected through a semistructured interview and analyzed through descriptive and analytic statistics. The prevalence of musculoskeletal pain corresponded to $70.1 \%$, with strong and unbearable intensity in $25.5 \%$ of the cases.

Results: the workers were between 19 and 34 old; $95 \% \mathrm{CI}=1.03-1.27$, those without time for leisure $\mathrm{RPa}=1.14 ; 95 \% \mathrm{CI}=1.03-1.27$ and those who sometimes have time for leisure $\mathrm{RPa}=1.10 ; 95 \% \mathrm{CI}=1.02-1.20$ presented higher prevalence rates for musculoskeletal pain than the other groups. Conclusion: no association was verified between musculoskeletal pain and occupational factors. Nevertheless, the workers perform their activities even with musculoskletal symptoms, which suggests attention.

DESCRIPTORS: Nursing. Occupational health. Musculoskeletal pain. Hospital cleaning service.

\section{PREVALÊNCIA E FATORES ASSOCIADOS À DOR MUSCULOESQUELÉTICA EM TRABALHADORES DO SERVIÇO HOSPITALAR DE LIMPEZA}

\section{RESUMO}

Objetivo: avaliar a prevalência e os fatores associados à ocorrência de dor musculoesquelética em trabalhadores do serviço hospitalar de limpeza.

Método: estudo transversal, realizado com 157 trabalhadores terceirizados de um hospital universitário do Rio Grande do Sul, Brasil. Os dados foram coletados por meio de entrevista estruturada, e analisados através da estatística descritiva e analítica. A prevalência de dor musculoesquelética foi de 70,1\%, com intensidade forte e insuportável em 25,5\% dos casos.

Resultados: os trabalhadores entre 19 e 34 anos $\mathrm{RPa}=1,14$; IC95\%=1,03-1,27, os que não tem tempo para o lazer RPa=1,14; IC95\%=1,03-1,27 e os que às vezes tem tempo para o lazer $\mathrm{RPa}=1,10$; IC95\% $=1,02-1,20$ apresentaram prevalências mais elevadas de dor muscular esquelética quando comparados aos demais grupos.

Conclusão: não foi evidenciada associação entre a dor muscular esquelética com fatores laborais. No entanto, os trabalhadores exercem suas atividades na presença de sintomas osteomusculares, o que sugere atenção.

DESCRITORES: Enfermagem. Saúde do trabalhador. Dor musculoesquelética. Serviço hospitalar de limpeza. 


\section{REVALENCIA Y FACTORES ASOCIADOS AL DOLOR MUSCOLOESQUELÉTICO EN TRABAJADORES DEL SERVICIO HOSPITALAR DE LIMPIEZA}

\section{RESUMEN}

Objetivo: evaluar la prevalencia y los factores asociados a la ocurrencia del dolor muscoloesquelético en trabajadores del servicio hospitalario de limpieza.

Método: estudio transversal, realizado con 157 trabajadores tercerizados de un hospital universitario de Rio Grande do Sul, Brasil. Los datos fueron recolectados por medio de entrevista estructurada y, analizados a través de estadística descriptiva y analítica. La prevalencia de dolor musculoesquelético fue de 70,1\% con intensidad fuerte e insoportable en 25,5\% de los casos.

Resultados: los trabajadores entre 19 y 34 años $\mathrm{RPa}=1,14$; IC95\%=1,03-1,27, los que no tenían tiempo de ocio RPa=1,14; IC95\%=1,03-1,27y los que algunas veces tenían tiempo de ocio $\mathrm{RPa}=1,10$; IC95\%=1,02-1,20, presentaron prevalencias más elevadas de dolor muscular y esquelético que los otros grupos.

Conclusión: no fue evidenciada asociación entre dolor musculoesquelético con factores laborales. Sin embargo, los trabajadores ejercen sus actividades en la presencia de síntomas osteomusculares, lo que sugiere atención.

DESCRIPTORES: Enfermería. Salud laboral. Dolor muscoloesquelético. Servicio de limpieza en hospital.

\section{INTRODUCTION}

The workers from the hospital cleaning service (HCS) used to be restricted to operational factors and were not held responsible for keeping the environment safe for the workers and patients. ${ }^{1}$ This maintenance takes place through the removal of dirt, unwanted waste and microorganisms in the environment, contributing to the reduction of environmentrelated hospital infection ${ }^{1}$ and occupational accident rates. Nevertheless, they belong to a category that is sometimes forgotten in the labor context but is exposed to changes in the job world and to a high risk of burnout and both physical and mental illness. ${ }^{2}$

The HCS workers are usually hired by outsourced companies and, as reflexes of outsourcing, turnover, cost control and wage restraint stand out. ${ }^{3}$ Their profile is marked by early inclusion in the job market, low qualification, low wages and lack of social benefits. ${ }^{4-5}$ They commonly develop activities that require considerable physical effort, and chemical, biological, mental and ergonomic risks are also present in their daily work. ${ }^{4}$

In this paper, we highlight the risk situations that are favorable to the occurrence of musculoskeletal pain (MSP). These include the burden put on body segments in certain movements, excessive strength to accomplish some tasks, repetitive effort and unbalanced bodily postures, besides the existing ergonomic conditions in the organization of the work and the environmental factors. ${ }^{6}$

In this study, MSP refers to reports of pain or discomfort in the previous seven days, in the neck, shoulders, upper limbs, back, hips and lower limbs. It can derive from the abovementioned factors and from work-related musculoskeletal diseases. These disorders cause pain in bones, joints, muscles or surrounding structures, which can be classified as acute or chronic, focal or diffuse. ${ }^{7}$

Concerning its prevalence, opinions are unanimous that back pain is the most prevalent (30 to $40 \%$ ), followed by neck and shoulder pain (15 to $20 \%$, respectively). ${ }^{7}$ The greatest muscular demand is put on the spine, mainly in workers who accomplish activities with great physical effort to lift, transport and carry materials, a predominant characteristic in civil construction. ${ }^{8}$ As a preventive strategy to minimize this kind of problem, the work places need to be reshaped and equipment needs to be used to carry heavy loadings. ${ }^{8}$

Other causes of MSP include tendinitis, neuropathies, myalgia and fractures. ${ }^{7}$ The consequences in Brazil as well as in industrialized countries are increased costs due to absence from work and retirement. ${ }^{9}$ It is considered an important public health problem, being one of the main causes of absenteeism, search for medical care and disability for work. ${ }^{10}$

The importance for nursing to address the HCS workers is due to the fact that, overall, besides the care, educative and management functions inherent in the profession, nurses have been invited in hospitals to serve on the team of Occupational Health and Safety Services, acting in the prevention of occupational health problems, which broadens their role as health promoters and focuses their attention on the workers and the health conditions deriving from the work process. ${ }^{5}$ In addition, the limited visibility of this group of workers (HCS) is considered, in the job environments as well as in scientific research.

In this context, the objective was to assess the prevalence and factors associated with the occurrence of musculoskeletal pain in HCS workers 
from a public teaching hospital in the state of Rio Grande do Sul, Brazil. Thus, the goal is to support the planning of improvement in the production processes of HCS workers, with a view to reducing the occurrence of MSP.

\section{METHOD}

Cross-sectional study that used the database of the research entitled "Assessment of Work and Health Conditions of Hospital Cleaning Service Workers", approved by the Research Ethics Committee at Universidade Federal de Santa Maria (UFSM) (CAAE: 13106313.1.0000.5346, on February $\left.26^{\text {th }} 2013\right)$. This study design permits analyzing the characteristics of a certain population, according to specific variables and their distribution patterns, as well as testing for associations among the investigated variables. ${ }^{10}$

The place of study was a public university hospital in the state of Rio Grande do Sul, Brazil. At that institution, the HCS workers are outsourced. The eligible population consisted of 159 workers. Of these, 157 participated by answering the questionnaire $(98.7 \%)$. The losses $(1.3 \%)$ resulted from refusals to participate. All of them were included in the research, except for the workers who were on leave or who were absent for any reason during the data collection period.

The data were collected at the workplace and during the subjects' shift (morning, afternoon and night), between March and April 2013, by previously trained collectors. The workers were invited to participate individually and in a private room and, after they agreed, two copies of the Free and Informed Consent Form were signed, in compliance with Resolution 466/2012.

Based on literature evidence about the low education level in this category of workers ${ }^{11}$ and to control the quality of the data collection, we chose to have the collectors read the questions. Therefore, the participants received a copy of the tool to follow the reading and visualize the alternative answers. Based on their answer, the collector registered the response with the participant's knowledge.

For this study, two blocks from the research tool were used. Block A, which the researchers had elaborated, consisted of the following independent variables: a) sociodemographic: sex (female and male); age (full years, later ranked as 19 to 34 years, 35 to 44 years, 45 to 60 years); education (primary, secondary and higher education); skin color/race (white and other: black, mulatto, yellow, indige- nous); marital situation (married, single, widowed/ separated/divorced) and number of children under six years of age (none, one and two children); b) jobrelated: function performed (cleaning servant and aid); shift (day and nighttime); length of work at the institution and on the job (in months, later ranked at less or more than two years); time for leisure (no, yes and sometimes); other job (no and yes); overtime (no and yes); participation in training (no, yes and sometimes), family income (in reais) and satisfaction with remuneration (in percentages from 0 till 100); and c) health variables: smoking (never smoked, smoked but quit and yes); body mass index (weight and height, later ranked as underweight, normal, overweight and obesity), ${ }^{12}$ medication use (no and yes) and need for medical and psychological attendance in previous year (no and yes).

Block B consisted of the question on the MSP (dependent variable), collected by means of a visual analogue scale (0 to 10$) \cdot{ }^{13}$ Workers with MSP were defined as those workers who positively answered the question "In the past seven days, did you feel pain or discomfort in any of these regions: neck, shoulders, upper limbs, back, hips and lower limbs?".

The data were inserted in the software Epiinfo ${ }^{\circledR}$, version 6.4 , with independent double data entry. After checking for errors and inconsistencies, the data were analyzed in the software PASW Statistics ${ }^{\circledR}$ (Predictive Analytics Software, by SPSS Inc., Chicago - USA) version 18.0 for Windows.

Initially, descriptive statistics were calculated for the sociodemographic, job, health and MSP characteristics. For the qualitative variables, the absolute (n) and relative (\%) frequencies were calculated. For the quantitative variables, means and standard deviations (SD) were used in case of normal distribution, and median, interquartile interval, minimum and maximum when the distribution was not normal.

The perceived MSP in the past week was assessed by means of a numerical scale from zero to ten, with zero corresponding to the absence of pain and ten to the most intense pain felt. ${ }^{13}$ Later, it was ranked as: absent (0), weak pain (1-3), moderate pain (4-6), strong pain (7-9) and unbearable (10). Finally, the MSP was dichotomized as absent and present. To analyze the BMI, the following formula was used: weight/(height $)^{2}$ and the pain was ranked according to the international standards for adults of the World Health Organization. ${ }^{12}$

Then, bivariate analysis was applied, testing the association between the MSP and the sociodemographic, occupational and health variables, through the chi-squared test or Fisher's exact test (for tables 
with expected frequencies inferior to 5), adopting significance levels of $5 \%$. For the comparison of means, the Mann-Whitney test was used. The analysis was also developed by means of the Poisson regression to check for associations adjusted by possible confounding factors (variables associated to the outcome with $p<0.25$ ) between pain and the research variables. Therefore, the chi-square test, the prevalence ratio and the respective confidence intervals $(95 \% \mathrm{CI})$ were adopted.

This research complies with National Health Council Resolution N. 466/2012.

\section{RESULTS}

The main sociodemographic characteristics of the HCS workers are: predominantly female $(87.9 \%)$, between 45 and 60 years of age $(35.7 \%)$, with an average age of 39.9 years $( \pm 9.78)$ and (finished and unfinished) secondary education (54.8\%). A small part had finished higher education or not $(3.2 \%)$. A majority indicated being white $(63.7 \%)$, married $(64.3 \%)$, not having children younger than six years of age $(59.2 \%)$ and gaining an average per capita family income of $\mathrm{R} \$ 830.00$.

What the job profile is concerned, the majority worked as a cleaning servant $(65.6 \%)$; during the day $(80.9 \%)$, between 6 and 12 hours per day and 44 hours per week. The length of experience at the institution and on the job was up to two years
(63.1\% and $69.4 \%$, respectively); $59.3 \%$ indicated having time for leisure sometimes and $88.5 \%$ did not have another job. Nevertheless, those participants who had another simultaneous job (11.5\%) worked between three and 36 hours per week on the other job. As for overtime, 51 (32.5\%) participants affirmed working overtime, with an average 13.4 hours/ month ( \pm 9.5 ); $72 \%$ indicated that they sometimes received training and $67.5 \%$ were satisfied with their remuneration.

The health profile of the HCS workers indicated $49.7 \%$ of former smokers and smokers and $70.7 \%$ with excess weight (BMI superior to 25$){ }^{12}$ In this group, $36.9 \%$ suffered from overweight and $33.8 \%$ from degree I, II and III obesity. Among the participants, $51 \%$ used some type of medication, the most reported being: contraceptive drugs (43\%), antidepressants (16.5\%) and anti-hypertensive drugs $(12.7 \%)$. As for the need for medical and psychological care, in the past year, $58.6 \%$ and $6.4 \%$, respectively, answered positively. Among the participants who got ill, mild mental disorders $(31.8 \%)$ and musculoskeletal problems (15.9\%) were the most prevalent medical diagnoses.

The prevalence of musculoskeletal pain reported in the past seven days before the interview corresponded to $70.1 \%(\mathrm{n}=110)$. Among these participants, $25.5 \%(n=40)$ classified it as strong and unbearable.

Table 1 - Frequencies of musculoskeletal pain in hospital cleaning workers according to the sociodemographic profile. Rio Grande do Sul, Brazil, 2013. (n=157)

\begin{tabular}{|c|c|c|c|c|c|}
\hline \multirow[b]{2}{*}{ Variables } & \multicolumn{2}{|c|}{ Frequencies } & \multicolumn{2}{|c|}{ Musculoskeletal pain } & \multirow[b]{2}{*}{$\mathrm{p}$} \\
\hline & $\mathbf{n}$ & $(\%)$ & $\begin{array}{c}\text { No } \\
\text { n(\%) }\end{array}$ & $\begin{array}{c}\text { Yes } \\
\mathbf{n}(\%)\end{array}$ & \\
\hline Sex & & & & & 0.483 \\
\hline Male & 19 & 12.1 & $7(36.8)$ & $12(63.1)$ & \\
\hline Female & 138 & 87.9 & $40(29.0)$ & $98(71.0)$ & \\
\hline Age range & & & & & 0.031 \\
\hline 19 to 34 years & 51 & 32.5 & $12(23.5)$ & $39(76.5)$ & \\
\hline 35 to 44 years & 50 & 31.8 & $11(22.0)$ & $29(78.0)$ & \\
\hline 45 to 60 years & 56 & 35.7 & $24(42.9)$ & $32(57.1)$ & \\
\hline Education & & & & & 0.871 \\
\hline Primary education & 66 & 42.0 & $20(30.3)$ & $46(69.7)$ & \\
\hline Secondary education & 86 & 54.8 & $25(29.1)$ & $61(70.9)$ & \\
\hline Higher education & 5 & 3.2 & $2(40.0)$ & $3(60.0)$ & \\
\hline Color / Race & & & & & 0.483 \\
\hline White & 100 & 63.7 & $28(28.0)$ & $72(72.0)$ & \\
\hline Other* & 57 & 36.3 & 19 (33.3) & $38(66.7)$ & \\
\hline
\end{tabular}




\begin{tabular}{|c|c|c|c|c|c|}
\hline \multirow[b]{2}{*}{ Variables } & \multicolumn{2}{|c|}{ Frequencies } & \multicolumn{2}{|c|}{ Musculoskeletal pain } & \multirow[b]{2}{*}{$\mathrm{p}$} \\
\hline & $\mathbf{n}$ & $(\%)$ & $\begin{array}{c}\text { No } \\
\text { n(\%) }\end{array}$ & $\begin{array}{c}\text { Yes } \\
\text { n(\%) }\end{array}$ & \\
\hline Marital Situation & & & & & 0.113 \\
\hline Married & 101 & 64.3 & $26(25.7)$ & $75(74.3)$ & \\
\hline Single & 33 & 21.0 & $10(30.3)$ & $23(69.7)$ & \\
\hline Widowed/separated/divorced & 23 & 14.7 & $11(47.8)$ & $12(52.1)$ & \\
\hline Children $<6$ years $\uparrow(\mathrm{n}=135)$ & & & & & 0.028 \\
\hline None & 93 & 68.9 & $33(35.5)$ & $60(64.5)$ & \\
\hline One child & 35 & 25.9 & $4(11.4)$ & $31(85.6)$ & \\
\hline Two children & 7 & 5.2 & $2(28.6)$ & $5(71.4)$ & \\
\hline
\end{tabular}

* Other race: black, mulatto, yellow, indigenous; $\uparrow n=135$ of the participants have children.

According to table 1, a statistical significant difference was found for the occurrence of MSP among the HCS workers between 35 and 44 years of age $(78 \%)$ and with one child younger than six years of age (85.6\%). On the opposite, participants between 45 and 60 years of age and without children younger than six years of age $(42.9 \%$ and $35.5 \%$, respectively) are the least affected by MSP.

Table 2 - Frequencies of musculoskeletal pain in hospital cleaning service workers according to job profile. Rio Grande do Sul, Brazil, 2013. (n=157)

\begin{tabular}{|c|c|c|c|c|c|}
\hline \multirow[b]{2}{*}{ Variables } & \multirow[b]{2}{*}{$\mathbf{n}$} & \multirow[b]{2}{*}{$\%$} & \multicolumn{2}{|c|}{ Musculoskeletal pain } & \multirow[b]{2}{*}{ p } \\
\hline & & & $\begin{array}{c}\text { No } \\
\mathbf{n}(\%)\end{array}$ & $\begin{array}{c}\text { Yes } \\
\text { n(\%) }\end{array}$ & \\
\hline Function & & & & & 0.246 \\
\hline Cleaning servant & 103 & 65.6 & $34(33.0)$ & $69(67.0)$ & \\
\hline Cleaning aid & 54 & 34.4 & $13(24.1)$ & $41(75.9)$ & \\
\hline Work shift & & & & & 0.075 \\
\hline Daytime & 127 & 80.9 & $34(26.8)$ & 93 (73.2) & \\
\hline Nighttime & 30 & 19.1 & $13(43.3)$ & 17 (56.7) & \\
\hline Length of experience at the institution & & & & & 0.896 \\
\hline$<2$ years & 99 & 63.1 & $30(30.3)$ & 69 (69.7) & \\
\hline$\geq 2$ years & 58 & 36.9 & $17(29.3)$ & $41(70.7)$ & \\
\hline Length of experience on the job & & & & & 0.203 \\
\hline$<2$ years & 109 & 69.4 & $36(33.0)$ & $73(67.0)$ & \\
\hline$\geq 2$ years & 48 & 30.6 & $11(22.9)$ & 37 (77.1) & \\
\hline Time for leisure & & & & & 0.030 \\
\hline No & 17 & 10.8 & $2(11.8)$ & $15(88.2)$ & \\
\hline Yes & 47 & 29.9 & $10(21.3)$ & 37 (78.7) & \\
\hline Sometimes & 93 & 59.3 & $35(37.6)$ & $58(62.4)$ & \\
\hline Other job & & & & & 0.738 \\
\hline No & 139 & 88.5 & $41(29.5)$ & $98(70.5)$ & \\
\hline Yes & 18 & 11.5 & $6(33.3)$ & $12(66.7)$ & \\
\hline Overtime & & & & & 0.399 \\
\hline No & 106 & 67.5 & $34(32.1)$ & $72(67.9)$ & \\
\hline Yes & 51 & 32.5 & $13(25.5)$ & $38(74.5)$ & \\
\hline Participation in training & & & & & 0.483 \\
\hline No & 21 & 13.4 & $5(23.81)$ & $16(76.2)$ & \\
\hline Yes & 23 & 14.6 & $7(30.4)$ & $16(69.6)$ & \\
\hline Sometimes & 113 & 72.0 & $35(31.0)$ & $78(69.0)$ & \\
\hline
\end{tabular}




\begin{tabular}{|c|c|c|c|c|c|}
\hline \multirow[b]{2}{*}{ Variables } & \multirow[b]{2}{*}{$\mathbf{n}$} & \multirow[b]{2}{*}{$\%$} & \multicolumn{2}{|c|}{ Musculoskeletal pain } & \multirow[b]{2}{*}{$\mathbf{p}$} \\
\hline & & & $\begin{array}{c}\text { No } \\
\mathbf{n}(\%)\end{array}$ & $\begin{array}{c}\text { Yes } \\
\text { n(\%) }\end{array}$ & \\
\hline Satisfaction with remuneration $(\%)^{*}$ & & & & & 0.234 \\
\hline $0 \mid-20$ & 5 & 3.2 & $2(40)$ & $3(60)$ & \\
\hline $20 \mid-40$ & 9 & 5.8 & $4(44.4)$ & $5(55.6)$ & \\
\hline $40 \mid--60$ & 36 & 23.1 & 7 (19.4) & $29(80.6)$ & \\
\hline $60 \mid--80$ & 49 & 31.4 & $13(26.5)$ & $36(73.5)$ & \\
\hline $80 \mid--100$ & 57 & 36.5 & $21(36.8)$ & $36(63.2)$ & \\
\hline
\end{tabular}

* $n=156$ answered this item.

According to table 2, a statistically significant difference was evidenced, in that a higher percent- age of MSP was found among workers who affirmed they had no time for leisure $(88.2 \%)$.

Table 3 - Frequencies of musculoskeletal pain in hospital cleaning service workers according to health profile. Rio Grande do Sul, Brazil, 2013. (n=157)

\begin{tabular}{|c|c|c|c|c|c|}
\hline \multirow[b]{2}{*}{ Variables } & \multirow[b]{2}{*}{$\mathbf{n}$} & \multirow[b]{2}{*}{$\%$} & \multicolumn{2}{|c|}{ Musculoskeletal pain } & \multirow[b]{2}{*}{ p } \\
\hline & & & $\begin{array}{c}\text { No } \\
\text { n(\%) }\end{array}$ & $\begin{array}{c}\text { Yes } \\
\mathbf{n}(\%)\end{array}$ & \\
\hline Smoking & & & & & 0.708 \\
\hline Has never smoked & 79 & 50.3 & $26(32.9)$ & $53(67.1)$ & \\
\hline Smoked but quit & 27 & 17.2 & $7(25.9)$ & $20(74.1)$ & \\
\hline Yes, smokes & 51 & 34.5 & $14(27.5)$ & $37(52.5)$ & \\
\hline Body Mass Index & & & & & 0.291 \\
\hline Low weight $(<18.5)$ & 3 & 1.9 & $1(33.3)$ & $2(66.7)$ & \\
\hline Normal (BMI between 18.5 and 24.9) & 43 & 27.4 & $10(23.3)$ & $33(76.7)$ & \\
\hline Overweight (BMI between 25 and 29) & 58 & 36.9 & $23(39.7)$ & $35(60.3)$ & \\
\hline \multicolumn{6}{|l|}{ Obesity (BMI>=30) } \\
\hline $\begin{array}{l}30|--| 34.9 \\
35|-| 39.9\end{array}$ & $\begin{array}{r}40 \\
6\end{array}$ & $\begin{array}{r}25.5 \\
3.8\end{array}$ & $\begin{array}{l}9(22.5) \\
2(33.3)\end{array}$ & $\begin{array}{r}31(77.5) \\
4(66.7)\end{array}$ & \\
\hline$>=40$ & 7 & 4.5 & $2(28.6)$ & $5(71.4)$ & \\
\hline Medication use & & & & & 0.084 \\
\hline No & 77 & 49.1 & $28(36.4)$ & $49(63.6)$ & \\
\hline Yes & 80 & 50.9 & $19(23.8)$ & $61(76.3)$ & \\
\hline Need for medical care (past year) & & & & & 0.369 \\
\hline No & 65 & 41.4 & $22(33.8)$ & $43(66.2)$ & \\
\hline Yes & 92 & 58.6 & $25(27.2)$ & $67(72.8)$ & \\
\hline Need for psychological care (past year) & & & & & $0.462^{*}$ \\
\hline No & 147 & 93.6 & $45(30.6)$ & $102(69.4)$ & \\
\hline Yes & 10 & 6.4 & $2(20.0)$ & $8(80.0)$ & \\
\hline
\end{tabular}

* Fisher's Exact test

In the assessment of the health profile variables (Table 3), no statistically significant difference was identified among the groups $(\mathrm{p}>0.05)$. 
Table 4 - Gross and adjusted analyses for association between musculoskeletal pain and sociodemographic, job, habit and health variables in hospital cleaning service workers. Rio Grande do Sul, Brazil, 2013. ( $\mathrm{n}=157)$

\begin{tabular}{|c|c|c|c|}
\hline \multirow{2}{*}{ Variables } & \multicolumn{2}{|c|}{ Musculoskeletal pain } & \multirow{2}{*}{$\mathrm{p}$} \\
\hline & \multicolumn{2}{|c|}{$P^{*}(95 \% C I)$} & \\
\hline \multicolumn{4}{|l|}{ Gross analysist } \\
\hline \multicolumn{4}{|l|}{ Age (years/tertile) } \\
\hline 19 to 34 & 1.12 & $1.01-1.25$ & 0,031 \\
\hline 35 to 44 & 1.13 & $1.02-1.26$ & 0,020 \\
\hline 45 to 60 & 1.00 & & \\
\hline \multicolumn{4}{|l|}{ Marital situation } \\
\hline Single/no partner & 1.00 & & \\
\hline Married & 1.07 & $0.98-1.18$ & 0,137 \\
\hline \multicolumn{4}{|l|}{ Children $<6$ years } \\
\hline None & 1.00 & & \\
\hline 1 child & 1.15 & $1.06-1.24$ & 0,001 \\
\hline 2 children & 1.04 & $0.85-1.28$ & 0,692 \\
\hline \multicolumn{4}{|l|}{ Work shift } \\
\hline Daytime & 1.11 & $0.98-1.25$ & 0,105 \\
\hline Nighttime & 1.00 & & \\
\hline \multicolumn{4}{|l|}{ Leisure time } \\
\hline No & 1.16 & $1.05-1.28$ & 0,004 \\
\hline Sometimes & 1.10 & $1.01-1.20$ & 0,035 \\
\hline Yes & 1.00 & & \\
\hline \multicolumn{4}{|l|}{ Medication use } \\
\hline Yes & 1.08 & $0.99-1.17$ & 0,084 \\
\hline No & 1.00 & & \\
\hline \multicolumn{4}{|l|}{ Adjusted model 1‡ } \\
\hline \multicolumn{4}{|l|}{ Age (years/tertile) } \\
\hline 19 to 34 & 1.15 & $1.02-1.29$ & 0,025 \\
\hline 35 to 44 & 1.08 & $0.96-1.21$ & 0,189 \\
\hline 45 to 60 & 1.00 & & \\
\hline \multicolumn{4}{|c|}{ Children younger than 6 years of age } \\
\hline None & 1.00 & & \\
\hline 1 child & 1.08 & $0.99-1.18$ & 0,064 \\
\hline 2 children & 0.94 & $0.79-1.14$ & 0,543 \\
\hline \multicolumn{4}{|l|}{ Work shift } \\
\hline Daytime & 1.11 & $0.97-1.26$ & 0,130 \\
\hline Nighttime & 1.00 & & \\
\hline \multicolumn{4}{|l|}{ Leisure time } \\
\hline No & 1.13 & $1.02-1.23$ & 0,020 \\
\hline Sometimes & 1.08 & $0.98-1.18$ & 0,124 \\
\hline Yes & 1.00 & & \\
\hline \multicolumn{4}{|l|}{ Medication use } \\
\hline Yes & 1.11 & $1.02-1.21$ & 0,015 \\
\hline No & 1.00 & & \\
\hline \multicolumn{4}{|l|}{ Adjusted model $2 \S$} \\
\hline \multicolumn{4}{|l|}{ Age (years/tertile) } \\
\hline 19 to 34 & 1.14 & $1.03-1.27$ & 0,012 \\
\hline 35 to 44 & 1.11 & $0.99-1.23$ & 0,060 \\
\hline
\end{tabular}




\begin{tabular}{|c|c|c|c|}
\hline \multirow{2}{*}{ Variables } & \multicolumn{2}{|c|}{ Musculoskeletal pain } & \multirow[b]{2}{*}{$\mathbf{p}$} \\
\hline & \multicolumn{2}{|c|}{$P^{*}(95 \% C I)$} & \\
\hline 45 to 60 & 1.00 & & \\
\hline \multicolumn{4}{|l|}{ Leisure time } \\
\hline No & 1.14 & $1.03-1.27$ & 0,013 \\
\hline Sometimes & 1.10 & $1.02-1.20$ & 0,021 \\
\hline Yes & 1.00 & & \\
\hline \multicolumn{4}{|l|}{ Medication use } \\
\hline Yes & 1.08 & $0.99-1.18$ & 0,067 \\
\hline No & 1.00 & & \\
\hline
\end{tabular}

*PR: prevalence ratio; 95\%CI: confidence interval; †Gross analysis: variables with significance $<0.25$ in the bivariate analysis; $\ddagger$ Adjusted model $1(\alpha<0.10)$ : PR adjusted for age, children younger than six years of age, shift, time for leisure and medication use; §Adjusted model 2 ( $\alpha<0.05)$ : PR adjusted for age, leisure time and medication use.

Table 2 presents the associations adjusted for possible confounding factors (variables associated with the outcome with $\mathrm{p}<0.25$ ) between pain and the research variables. The workers with higher prevalence rates for MSP were between 19 and 34 years old $(\mathrm{PRa}=1.14 ; 95 \% \mathrm{CI}=1.03-1.27)$, without time for leisure (PRa=1.14; 95\% CI=1.03-1.27) and those who sometimes had time for leisure $(\mathrm{PRa}=1.10$; $95 \% \mathrm{CI}=1.02-1.20)$.

\section{DISCUSSION}

The prevalence of musculoskeletal pain was significant during the past seven days $(70.1 \%)$ in the following regions: neck, shoulders, upper limbs, back, hips and lower limbs. This result was similar to the study of urban cleaning workers, which assessed the prevalence in the past 12 months $(77.4 \%)^{11}$ and of nursing workers (73.1\%). ${ }^{14}$ The nursing team used to execute the cleaning of the wards, instead of workers specifically designated for that activity. ${ }^{1}$

Back pain has been highlighted as a result of unbalanced postures in the work environment and as one of the most common causes of MSP. ${ }^{15}$ In the case of cleaning workers, this can be due to the fact that the spine is frequently injured, as it absorbs most of the body weight and the weights the workers carry. ${ }^{15}$

In this study, the significant percentage of HCS workers who reported feeling strong and unbearable MSP is emphasized (25.5\%). They also reported moderate $(26.8 \%)$, weak $(17.8 \%)$ and absent $(29.9 \%)$ MSP. In a study ${ }^{16}$ of cleaning workers from a university, the following factors were identified associated with this increased intensity: use of inappropriate tools, repetitiveness of tasks, improper postures and lack of work organization.

The most uncomfortable posture the cleaning workers from a university mentioned was standing with the torso twisted, used in most activities, such as sweeping and cleaning floors. ${ }^{16}$ Another important activity they performed is the manual transportation of loadings, responsible for countless cases of back pain. ${ }^{15}$ The consequences of MSP caused by back pain include the partial or complete impediment to perform job tasks, leading to the search for health care. ${ }^{15}$

In this study, the HCS workers between 19 and 34 years of age presented higher prevalence rates of MSP when compared to the older workers (45 to 60 years). A population-based study of adults in the South of Brazil also evidenced higher percentages (35.7\%) of MSP among young adults (20 to 34 years). ${ }^{17}$ In a study ${ }^{18}$ involving adolescents, which found a knowledge deficit on the correct bodily posture (way to bend down, stand, sleep, carry the backpack, move an object, etc.) shows that the orientations to prevent MSP should start in primary education. In this study, ${ }^{18}$ it was observed that MSP (back, neck and feet) was more prevalent in men and gradually progressed with age. This can be perpetuated in adult life and worsen pain conditions associated with certain job activities that required physical effort, like in the case of HCS workers. ${ }^{18}$

Differently from other studies, ${ }^{19-20}$ it was observed that MSP dropped with age. Plausible reasons include that workers with longer professional experience can be less susceptible to the negative effects of the work on their health, while younger workers tend to be in charge of the activities that entail greater physical requirements. ${ }^{19}$ The early insertion of this population in the job market may also be related with the MSP. ${ }^{2}$

Another important finding in this study refers to the fact that the workers who had no time or who sometimes had time for leisure reported a higher percentage of MSP (88.2\%). A study involving an adult population observed a direct relation between having no time for leisure and back pain. ${ }^{17}$ Unfortunately, the workers are not always satisfactorily remunerated, demanding another job or overtime to provide the family income, which influence the time available for leisure, making them vulnerable to the occurrence of MSP. ${ }^{21}$

Another finding in line with the literature is the higher prevalence of MSP in women and 
workers with children younger than six years of age $(71.0 \%$ and $88.6 \%$, respectively). In accordance with a population-based study, women presented a higher risk of back pain than men. ${ }^{17}$ The cleaning service can cause great physical wear for women, in combination with activities related to housework or care for small children, which require greater dedication to care and can cause more physical stress. ${ }^{5} \mathrm{~A}$ study of nursing workers evidenced that psychosocial variables, including stress, are associated with pain in central body regions (shoulders, thoracic and lumbar spine). ${ }^{14}$

Longer experience at the institution and on the job revealed a higher prevalence of MSP $(70.7 \%$ and $77.1 \%$, respectively, in line with the results of a study on urban cleaning workers that identified that the length of exposure to arduous activities contributes to the occurrence of MSP. ${ }^{11}$ The explanation derives from the effect of the cumulative trauma in the workers' body segments, related to the characteristics of the activities performance and the equipment used.

Despite mentions in the literature about the relation between smoking and MSP, in this study, no association was evidenced. This result should be analyzed with caution, as cigarette consumption reduces the resistance of the muscles responsible for stabilizing the body segments, such as the spine, predisposing to pain. It is also possible that nicotine affects the central nervous system, interfering in the individual's perceived pain. ${ }^{20}$ It is highlighted that former smokers presented the highest prevalence of MSP (74.1\%).

No association has been evidenced either between the change in body mass and MSP. Nevertheless, the increased BMI was accompanied by the increased prevalence of MSP ( $p>0.05)$. As opposed to these findings, in a study that assessed chronic back pain in adults, a positive association was identified between obesity and musculoskeletal problems. ${ }^{22}$ One plausible explanation is that overweight causes a biomechanical disequilibrium of the body and increases the recruiting of the anti-gravitational muscles, which can promote the occurrence of back pain..$^{22}$

In a study ${ }^{23}$ of nursing students, it was evidenced that only $3.5 \%$ have complementary education on the theme "pain". In that context, the need emerges to discuss this theme and other occupational health problems during the academic education of health workers, especially nursing professionals, with a view to diagnosing the prevalent problems and the existing gaps to prevent them. ${ }^{23}$

The main perspective in this study what nursing is concerned is to offer knowledge on illness in HCS workers, considering that these workers' management represents a new activity area in nurse management. The main responsibility in nurses' management of HCS is to guarantee the safety of workers and/or patients, as well as the cleaning of hospital services, rooms and common beds, consequently minimizing hospital infections and occupational accidents. ${ }^{1}$

\section{CONCLUSION}

This study demonstrated a high percentage of MSP in the investigated workers. The significantly associated factors were being younger and having no time for leisure. No relation was evidenced between MSP and occupational factors.

What the musculoskeletal pain is concerned, these study findings reveal the profile of the HCS workers affected by MCP, supporting the planning of effective measures to prevent this problem, with a view to guaranteeing the quality of the service provided and the workers' health and wellbeing. The characteristics of the workers at the HCS presented here provide input for nurse management as, at most hospitals, this professional is responsible for human resource sizing, supervising hygiene and cleaning activities and training. The nurse's participation in the Continuing Education Groups and Occupational Health and Safety Service is also underlined.

As study limitations, we highlight that the cross-sectional design does not permit inferences on causal relationships. The population size is also emphasized which, despite the census, resulted in a small number. This may have led to the nonidentification of associations, mainly concerning the job factors investigated. Nevertheless, the results are relevant and confirm the need for other studies with larger samples and longitudinal designs.

Finally, the interface between the hospital cleaning service and nursing should be highlighted, due to the contemporary nature of the theme and the challenge it represents for nurses' management activities, which can be a space for innovation in nursing.

\section{Acknowledgements}

To Universidade Federal de Santa Maria (Scientific Initiation Grant) and to the Brazilian Scientific and Technological Development Council (CNPqUniversal Call 2013) for funding the development of the research.

\section{REFERENCES}

1. Chaves LDP, Camelo SHH, Silva MR, Silva NM, Pereira AP. Hospital governance, hygiene and cleaning: nurse management space. Texto Contexto Enferm [Internet]. 2015 Out-Dez [cited 2016 Mar 09]; 24(4):925-34. Available from: http://www. scielo.br/pdf/tce/2015nahead/pt_0104-0707tce-201500004010014.pdf 
2. Silva LG, Haddad MCL, Domansky RC, Vituri DW. Capacidade para o trabalho entre trabalhadores de higiene e limpeza de um hospital universitário público. Rev Eletr Enf [Internet]. 2010 Mar-Nov [cited 2015 Jan 24];12(1):158-63. Available from: https:/ / www.fen.ufg. br/fen_revista/v12/n1/pdf/v12n1a19.pdf

3. Martins MIC, Molinaro A. Reestruturação produtiva e seu impacto nas relações de trabalho nos serviços públicos de saúde no Brasil. Ciênc Saúde Coletiva. 2013 Fev-Mar; 18(6):1667-76.

4. Andrade CB, Cocco MIM. Trabalho, envelhecimento e qualidade de vida: relatório final de iniciação científica. Campinas (SP): SAE/Unicamp; 1999.

5. Chillida MSP, Cocco MIM. Saúde do trabalhador e terceirização: perfil de trabalhadores de serviço de limpeza hospitalar. Rev Latino-Am Enfermagem. 2004 Mar-Abr; 12(2): 271-6.

6. Ministério da Saúde (BR). Instrução normativa INSS/ DC n ${ }^{\circ}$ 98, de 05 de dezembro de 2003: aprova Norma Técnica sobre Lesões por Esforços Repetitivos - LER ou Distúrbios Osteomusculares Relacionados ao Trabalho-DORT. Brasília (DF): MS; 2003.

7. Sociedade Brasileira para o Estudo da Dor SBED [Internet]. Ano mundial contra a dor musculoesquelética. São Paulo (SP): SBED, 2010 [cited 2015 Jan 24]. Available from: www.dor.org.br

8. Pereira CC, Debiase DF, Farias JM, Madeira K, Longen WC. Análise do risco ergonômico lombar de trabalhadores da construção civil através do método NIOSH. Rev Produção Online [Internet]. 2015 Jul-Set [cited 2016 Mar 09]; 15(3):914-24. Available from: https://www. producaoonline.org.br/rpo/article/view/1888

9. Leão ER, Silva MGP. Música e dor crônica músculoesquelética: o potencial evocativo de imagens mentais. Rev Latino-Am Enfermagem. 2004 Mar-Abr; 12(2):235-41.

10. Medronho RA, Block KV. Epidemiologia. $2^{\text {a }}$ ed. São Paulo (SP): Atheneu; 2008.

11. Pataro SMS, Fernandes RCP. Trabalho físico pesado e dor lombar: a realidade na limpeza urbana. Rev Bras Epidemiol. 2014 Jan-Mar; 1(1):17-30.

12. Associação Brasileira para o Estudo da Obesidade e da Síndrome metabólica (BR). Diretrizes brasileiras de obesidade 2009/2010. $3^{\mathrm{a}}$ ed. Itapevi (SP): AC Farmacêutica, 2009.

13. Jensen MP, Karoly P, Braver S. The measurement of clinical pain intensity: a comparison of six methods. Pain. 1986 Mar-Abr; 27(1):117-26.
14. Magnago TSBS, Lisboa MTL, Griep RH, Kirchhof ALC, Guido LA. Aspectos psicossociais do trabalho e distúrbio musculoesquelético em trabalhadores de enfermagem. Rev Latino-Am Enfermagem. 2010 MaiJun; 18 (3):429-35.

15. Glória IPS, Gonzales TO. Incapacidade por lombalgia em trabalhadores do Setor de limpeza da universidade de Mogi das Cruzes. Rev Bras Ciênc da Saúde. 2009 Out-Dez; 8(22):1-6.

16. Rocha C. Análise ergonômica da equipe de limpeza de uma universidade particular. [dissertação]. Porto Alegre (RS): Universidade Federal do Rio Grande do Sul, Programa de Pós-Graduação em Engenharia; 2003.

17. Ferreira GD, Silva MC, Rombaldi AJ, Wrege ED, Siqueira FV, Hallal PC. Prevalência de dor nas costas e fatores associados em adultos do Sul do Brasil: estudo de base populacional. Rev Bras Fisiote. 2011 Jan-Fev; 15(1):31-6.

18. Rebolho MCT, Rocha LE, Teixeira LR, Casarotto RA. Prevalência de dor músculo esquelética e percepção de hábitos posturais entre estudantes do ensino fundamental. Rev Med (São Paulo). 2011 Abr.-Jun; 90(2):68-77.

19. Cardoso JP, Ribeiro, IQB, Araújo TM, Carvalho FM, Reis EJFB. Prevalência de dor musculoesquelética em professores. Rev Bras Epidemiol. 2009 Dez; 12(4):604-14.

20. Almeida ICGB, Sá KN, Silva M, Baptista A, Matos MA, Lessa I. Prevalência de dor lombar crônica na população da cidade deSalvador. Rev Bras Ortopedia. 2008 Jan-Mar; 43(3): 96-102.

21. Maia MS, Ferreira MS, Carvalho NM. Análise de fatores de risco para dores osteomioarticulares em trabalhadores do setor de limpeza da Universidade da Amazônia: uma correlação com a qualidade de vida [dissertação]. Belém (PA): Universidade da Amazônia, Programa de Pós- Graduação em Fisoterapia; 2009.

22. Silva MC, Fassa AC, Valle NCJ. Dor lombar crônica em uma população adulta do sul do Brasil: prevalência e fatores associados. Cad Saude Publica. 2004 Mar-Abr; 20(2):377-85.

23. Lobo AJS, Martins JP. Pain: knowledge and attitudes of nursing students, 1 year follow-up [Internet]. Texto Contexto Enferm. 2013 Abr-Jun [cited 2016 Mar 09]; 22(2):311-7. Available from: http://www. scielo.br/scielo.php?script=sci_arttext\&pid=S010407072013000200006\&lng $=$ en\&nrm $=$ iso\&tlng $=$ en 